\title{
Formes théâtrales du trope de syllepse
}

\section{André Lascombes}

\section{(2) OpenEdition \\ Journals}

\section{Édition électronique}

URL : http://journals.openedition.org/shakespeare/1227

DOI : 10.4000/shakespeare.1227

ISSN : 2271-6424

Éditeur

Société Française Shakespeare

Édition imprimée

Date de publication : 1 novembre 1992

Pagination : 21-38

Référence électronique

André Lascombes, «Formes théâtrales du trope de syllepse », Actes des congrès de la Société française Shakespeare [En ligne], 10 | 1992, mis en ligne le 01 janvier 2007, consulté le 01 mai 2019. URL : http:// journals.openedition.org/shakespeare/1227 ; DOI : 10.4000/shakespeare.1227

Ce document a été généré automatiquement le 1 mai 2019.

(C) SFS 


\section{Formes théâtrales du trope de syllepse}

André Lascombes 